\title{
Organizational E-Government Readiness: An Investigation in Saudi
} Arabia

\author{
Ibrahim A. Alghamdi ${ }^{1}$, Robert Goodwin ${ }^{2} \&$ Giselle Rampersad $^{2}$ \\ ${ }^{1}$ Real Estate Development Fund, Ministry of Finance, Saudi Arabia \\ ${ }^{2}$ School of Computer Science, Engineering and Mathematics at Flinders University, Australia \\ Correspondence: Ibrahim A. Alghamdi, Real Estate Development Fund, Ministry of Finance, Saudi Arabia. \\ E-mail: algh0044@flinders.edu.au
}

Received: January 7, 2014

Accepted: February 28, $2014 \quad$ Online Published: April 18, 2014

doi:10.5539/ijbm.v9n5p14

URL: http://dx.doi.org/10.5539/ijbm.v9n5p14

\begin{abstract}
Given the significant investment in e-government programs internationally and the pertinent need for e-government readiness to allow such programs to germinate, the purpose of this study is to assess Organizational E-Government Readiness (OEGR) in Saudi Arabia. Based on interviews held with leading e-Government officials in Saudi Arabia, the study contributes a conceptual framework to evaluate OEGR factors in order to advance public sector transformation to E-Government. The study reveals that key factors pertaining to strategy, integration with national E-Government programs, access, portal, process, technology and people issues should be critically assessed in evaluating OEGR. The OEGR framework provided in this study is significant as it can be used by a range of stakeholders including information technology managers and policy makers in improving OEGR within the public sector and thus, in increasing the quality of public service delivery. Academic research examining the main internal organization factors leading to e-Government readiness is still sparse. The research extends the literature on e-readiness by adopting an organizational level perspective in an e-Government context.
\end{abstract}

Keywords: E-Government, readiness, developing countries, strategic planning, information and communication technology, public sector, Saudi Arabia

\section{Introduction}

Governments internationally have invested heavily in information and communication technology (ICT) projects as a stimulant for economic growth (Rojko et al., 2011). ICT budgets have increased exponentially despite economic crises (Ojiako, 2012). Receiving considerable investment, e-Government pertains to the application of ICT to provide e-services by government organizations at local, metropolitan, provincial and national levels. Benefits such as improved service delivery, public administration, cost efficiency and transparency are anticipated through e-Government (Gonzalez, 2007; Nfuka \& Rusu, 2007). However, the realization of such benefits is still a contentious issue (Alshehri \& Drew, 2010; Alghamdi et al., 2011). Consequently, there is a need for defining measures of success to improve awareness and to verify the feasibility of application of E-Government approaches (Andersen, 2010). To aid these efforts, research is needed to guide the assessment of E-Government at the organization level (Azab et al., 2009) as the majority of existing assessment models are more appropriate for the assessment of the overall implementation of E-Government at the country-level and remain limited in evaluating organizational-level e-Government projects.

Therefore, it is essential to create a more relevant model for public sector organizations that is applicable in the e-Government context. In contributing towards this aim, this study first reviews the readiness literature in general and the E-Government readiness literature in particular. Given the exploratory nature of this study in understanding the organizational, public sector, E-Government perspective, it is based on in-depth interviews with leading E-Government officials in Saudi Arabia. The World Economic Forum Global IT report (WEF, 2011) recognised Saudi Arabia for its best practice in networked readiness specifically and also praised its development in E-Government and public sector transformation. Therefore, the context of Saudi Arabia offers valuable insights given its commitment to E-Government and its notable progress in the area of in E-Government readiness. This study examines important drivers of E-Government readiness including strategy, user's access, national E-Government program, portal architecture, business processes, ICT infrastructure, and 
human resources.

\section{Organizational E-Government Readiness}

Existing e-Readiness models predominantly focus on a private sector context rather than that of the public sector. Koh et al. (2007) have assessed e-Readiness on three levels-strategic, system and data levels, albeit not in an e-Government context. Similarly, Haug et al. (2011) examine IT readiness in small and medium enterprises and explore company, management and employee characteristics. The technology readiness index has also focused on the private sector context, examining dimensions of optimism, innovation, comfort level and sense of security in industries such as the construction industry (Parasuraman, 2000; Kuo, 2013).

Furthermore, existing e-Readiness models are limited in the strategic implications that it provides to e-Government organizations (Al-Solbi, 2008). Alshehri and Drew's (2010) study states that without a clear strategy and a consequent lack of clear objectives, progress will lack direction and inevitably falter. Despite the commitment of Saudi Arabia to E-Government on the national scale, a closer examination at the organizational level is necessary as their findings reveal a number of barriers and challenges of e-Government adoption and diffusion including) the lack of a strategic plan, ii) the need for each government organization to align its goals with the national E-Government program, iii) the requirement for top management and leaders to take the responsibility in providing sufficient budget and resources in timely fashion, v) the shortage of IT professionals and required IT training courses, and vi) the lack of policy and regulation for e-usage (Alshehri \& Drew, 2010). Al-Osaimi's study (2007) in Saudi Arabia used an approach based on the Strategy, Technology, Organization, People and Environment (STOPE) framework for conducting e-Readiness assessments in public organizations (Al-Osaimi, 2007). However, the framework was geared for e-Readiness assessment at the national level rather than for assessing E-Government in the public sector organizations and in a specific region or country.

This move towards recognizing e-Government as an organizational-level strategic ICT is because it can play an important role in transforming public sector organizations. Several researchers consider that e-Government strategy should not be restricted to the ICT area only, but should also be viewed, managed, and assessed as an organizational concern. This is consistent with Bakry's (2004) STOPE framework for e-Readiness assessment model and Heeks's (2003) model for measuring Information, Technology, Processes, Objectives and values, Staffing and skills, Management systems and structures (ITPOSMO). These models collectively focus on organizational factors of information, IT, business processes, challenges, vision, objective, values, skills, training, management systems and architecture of portal, time and budget. However, these variables are not covered comprehensively in one model and exclude important additional factors such as users' access, national e-Government program and portal.

Existing e-Readiness models do not cover all factors that impact on OEGR in public sector particularly those integrated with organizational environment. Some e-Readiness models take into account factors including the quality of ICT infrastructure, stakeholder's expectations, and advantages accomplished from ICT implementation (APEC, 2000, 2008) for example, the Measurement and Evaluation Tool for e-Government Readiness (METTER) (United Nations, 2008, 2010, 2012). E-Readiness tools including those from the Center for International Development and Conflict Management (CIDCM), International Telecommunication Union (ITU), and the World Information Technology and Services Alliance (WITSA) do not include e-Government in their assessments. Also additional tools such as Center for International Development - Harvard University and IBM (CID), World Bank (Knowledge Assessment Methodology-KAM), World Economic Forum (Network Readiness Index-NRI), and U.S. Agency for International Development (USAID) do not cover all internal issues influencing e-Government readiness (bridges.org, 2005). While the literature recognizes the significance of OEGR (Andersen, 2010), empirical work remains limited. E-Government literature focuses on technical capabilities and relations and their consequences on e-services (Norris \& Lloyd, 2006; Andersen, 2010). However, E-Government literature remains limited in its examination of E-Government organizational strategy. Consequently, a comprehensive model to evaluate OEGR is necessary.

Extant E-Government research predominantly focuses on issues of functionality (Layne \& Lee, 2001; Millard, 2007). As an alternative, strategic orientation on government use of ICT should be considered. The study by Layne and Lee (2001), and the extension by Kim Andersen (2010) both focus on IT application and user's access, the latter more pertaining to the Internet only. However, both do not address other access considerations such as such as ATMs, PCs, fixed-line and mobile phones (WAP), and kiosks in public places. Furthermore, both studies do not cover the organizational e-Government strategy and its impact on other factors. Additionally, these studies do not cover e-Government programs and human resources in depth and how these can contribute towards successful E-Government. 
Other studies focus on the technical aspects (Chen, 2002; Safai-Amin, 2002) of ICT in an e-service delivery context. However, there is a considerable gap between what can be done by using ICTs and what has achieved in reality (OECD, 2003). E-Government initiatives are frequently unsuccessful because of a range of factors such as: the technical system is never implemented; the technology is discarded after implementation; key goals are not achieved (relating to cost, implementation timeframes, and capability) and/or they result in considerable unpredicted outcomes (Heeks, 2005b). However, several important factors to e-government readiness have surfaced from existing studies including access, organizational architecture, business process, ICT infrastructure and human resource dimension (Alghamdi et al., 2011). Therefore, this study will integrate these important areas that emerged from the literature review and validated them using in-depth interviews to provide a comprehensive model for OEGR.

\section{Methodology}

A qualitative approach was conducted for this study, given the exploratory nature of the enquiry. Interviews with leading e-Government officials were used within the context of Saudi Arabia E-Government organizations. The literature review acted as the basis upon which the research survey instrument was refined and results analysed. The purpose of the interviews was to survey the perceptions, plans, achievements and barriers encountered in e-Government readiness from the key informants' perspectives in Saudi Arabia. The interviews were face-to-face. Each interview ranged from an hour to an hour and a half.

Semi-structured interviews were conducted to allow for some set questions to be covered while giving leeway to probe issues further based on the interviewee's discussion (Kumar, 1996). Interviewees were chosen based on a preliminary survey and importance of organizations in Saudi Arabia. This is due to the fact that these organizations are in an appropriate position to give accurate details on barriers to OEGR (Niosi, 2006). Key officials were selected from these organizations based on their job position and the degree of their organizations' experience in electronic services provisions. Fifteen interviews were completed in this study (See Table 1). Access to these key officials was arranged through referrals from contacts in the related organizations.

Table 1. List of interviewees

\begin{tabular}{llll}
\hline Position & Title & Experience (year) & Interviewee\# \\
\hline Chief Information Officer (CIO) & Doctor & 23 & 1 \\
Head of the Internet and E-services & Engineer & 18 & 2 \\
Country Manager of IT Projects & none & 16 & 3 \\
Data Processing Manager & none & 20 & 4 \\
Information Technology Manager & none & 28 & 5 \\
General Supervisor of IT Application & Engineer & 14 & 6 \\
Dean, Doyenne of E-services & Doctor & 19 & 7 \\
General Manager of Information Technology & none & 32 & 8 \\
Information Technology Manager & none & 22 & 9 \\
Head of Electronic Services & Doctor & 18 & 10 \\
Information Technology Manager & none & 19 & 11 \\
Assistant Manager of IT Development & Engineer & 25 & 12 \\
Head of IT Development and Application & none & 17 & 13 \\
Information Technology Manager & none & 20 & 14 \\
Business Development Manager of E-services & Doctor & 13 & 15 \\
\hline
\end{tabular}

Interviews were recorded, transcribed and analysed for facilitating the accurate source of comments (Ticehurst \& Veal, 2000). In addition, it allowed the researcher to establish rapport with the interviewee through face-to-face contact, information assimilation and effective questioning (Blaxter et al., 2001). The content of the interviews was analyzed thematically. Codes were developed as patterns in the data emerged and were helpful in identifying and analyzing patterns of themes (Carson et al., 2001; Miles \& Huberman, 1994).

Steps were taken to address validity during this qualitative phase of the research. Primarily, multiple sources of information were used (Yin, 2009). While interviews comprise the primary source of information, supporting secondary data was also used. The secondary data was used for verifying and triangulating the findings of the interviews. Additionally, the sequence of evidence, tracing the conclusions to the interview summary and to the interview transcripts, was also maintained. These enhance construct validity and the reliability of the research, 
thus enhancing the quality of results (Yin, 2009).

\section{A Model for Organizational E-Government Readiness}

A model for organizational e-Government readiness emerged from the literature on information systems e-Readiness and e-Government together with the qualitative findings. As illustrated in Figure 1, this study integrates seven key areas which will be discussed further in this Section.

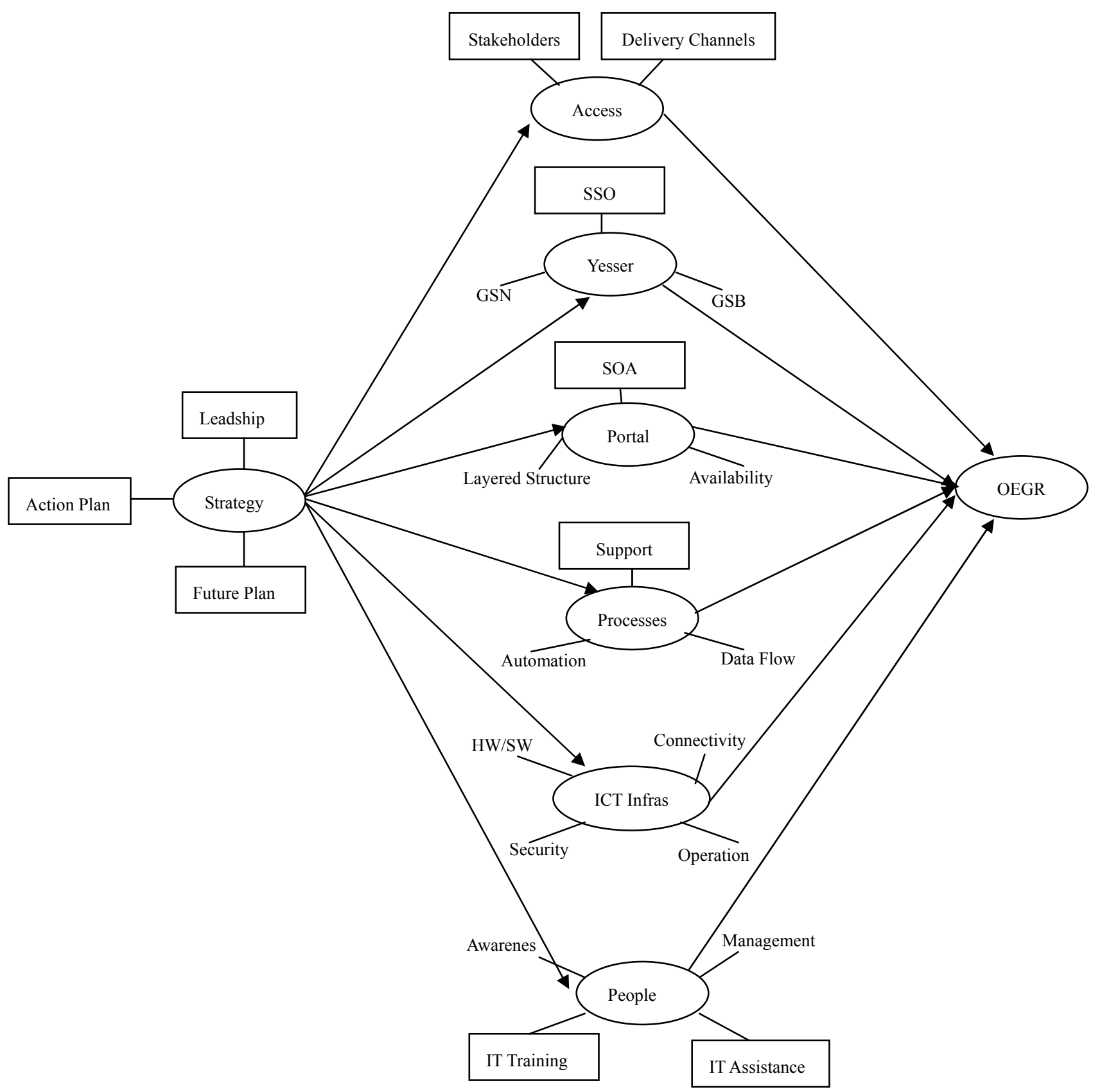

Figure 1. Suggested model for Saudi Arabia

Interviewees confirmed the findings in the literature that strategy is fundamental for e-Government adoption to be succeed (Bakry, 2004; Alshehri \& Drew, 2010; Alsobhi et al., 2009; Yesser, 2013). There was unanimous agreement among interviewees that the primary factor for e-Government organizational readiness is strategy, for example, Interviewee \# 10 stated that "Organizational e-Government strategy is important for any government organization". 
Interviewees also confirmed the importance of leadership for e-Government readiness (Interviewees \# 2, 3, 4, 5, 7, 9 and 10). Interviewee \# 7emphasised that, "leadership is important to ensure that the organization is e-ready". Many officials indicated that there is a need to create a leadership steering committee to ensure the progress of e-Government projects (Interview\# 2, 3, 10, 5 and 13) consistent with findings in the literature (Yesser, 2005, Bakry, 2004). The Head of Electronic Services (Interviewee \# 10) stressed that "an e-Government steering committee was formed to monitor and control all e-Government projects."

Interviewees confirmed the findings in the literature that action plans are important to ensure achievement of e-Government milestones and objectives (Bakry, 2004, Azab et al., 2009, World Bank, 2006). For instance, the Assistant Manager of IT Development (Interviewee \# 12) confirmed that "the e-Government strategy has an action plan with all important KPIs." A Chief Information Officer (CIO) (Interviewee \# 1) emphasised that "the action plan was part of the e-Government strategy for modernising the public sector by utilizing ICT".

Interviewees confirmed the findings in the literature that future development plans were an important component for strategy (World Bank, 2005, Bakry, 2004). The Assistant Manager of IT Development (Interviewee \# 12) confirmed that "the organization prepares ambitious future plans to upgrade the level of performance in different services. Such five-year plans include the creation of the infrastructure for the e-Government..." Interviewee \#4 stressed the importance of creating a clear e-Government future development plan "...the organization is adapting e-Government future development plans."

\subsection{User's Access}

Interviewees confirmed the findings in the literature that it is important to offer e-services to stakeholders including citizens (G2C), government agencies (G2G), private firms (G2B) and employees (G2E) (Ebrahim and Irani, 2005; World Bank, 2005; Yesser, 2013). Interviewees explained their e-services offered for example: "We offer $\mathrm{G} 2 \mathrm{C}$ e-services such as civil affairs, traffic and labour importation. We offer G2G e-services, including to the Ministry of Health... Also, we offer G2B services such the passport "NETHAM MOGEEM" system for entry visa" (Interviewee \# 2).

Additionally, interviewees confirmed that these groups need to have multi delivery channels for access. Access channels comprise online and offline channels of delivery through which products, services and information are utilized, accessed and communicated by various technologies such as Internet, ATMs, PCs, fixed-line and mobile phones (WAP), and kiosks in public places (Alsobhi et al., 2009, Heeks, 2005a, Moon, 2002). "Because of importance of user access, the organization offers different of delivery channels which are website, BPAY, ATMs and telephone" (Interviewee \# 3). Interviewee \# 3 stressed that "it is important to provide multi types of delivery channels for all stakeholders such as website, e-payment methods and mobile."

\subsection{National E-Government Program (Yesser)}

Interviewees felt that availability, compatibility and connectivity to the national e-Government program (Yesser, 2013) are vital for OEGR.

The qualitative research confirmed the need to develop Single Sign On (SSO) portals associated with the national portal to lead to effective integration of different governmental agencies (ICEGD, 2002; Lee, 2010; Yesser, 2013). "There is a strong need to give Yesser proper authority to ensure that public sector organizations are ready to connect via suitable SSO portals." (Interviewee \# 7)

Government Service Bus (GSB) is important to be the middle platform of integration and services for government e-services and transactions (Yesser, 2005). It launches ready-made integration codes using open standard, messaging, and freely joined Service Oriented Architecture (SOA) rules (Chappell, 2004). Many interviewees stressed the need to connect to compatible GSB properly. "Yesser does not provide either coordination with public sectors to ensure compatibility of connecting to GSN or GSB, technical help nor training, so that affects integration ...” (Interviewee \# 5).

The Government Security Network (GSN) is important in providing a secure communications network specially for electronic government transactions (Yesser, 2005). This network links government agencies to the e-Government Data Canter, should be established at the highest technical specifications and security for use in hosting the gate of the national electronic services, and the host site for e-Government program (Yesser, 2005).In this context, our in-depth interviews confirmed the importance and need to connect to an adequate GSN in order to be able to share secure information within government organizations. "Also, there is a delay in connecting with Government Security Network (GSN) and Government Service Bus which is offered by Yesser although the services provided through them are limited. That affected our e-Government readiness negatively." (Interviewee \# 3). 


\subsection{Portal}

It is important for organizations to have a high quality portal in order to offer effective e-services (Maheshwari et al., 2009). E-Government portals are essential in allowing organizations to extend e-services to citizens, other government agencies, businesses and employees integrated as single unit (Stauffacher, 2002). Portals mirror the sophistication of e-services in an organization and interviewees emphasised their importance in OEGR.

Availability reflects the types, levels, and number of services provided through a government public sector portal (Maheshwari et al., 2009). Portal availability is an essential aspect for e-Government services (UNDPEPA/ASPA, 2002; Yesser, 2013). Interviewees confirmed the findings in the literature that an availability of portal is necessary. "The organizationis aware of the importance of availability of advanced portal able to offer e-services..." (Interviewee \# 2). Interviewees (\# 7, 8, 10, 11, 12 and 15) reiterated the need for an adequate portal to be designed in early phases when setting the e-Government strategy.

Layered structures are commonly used in architectural design. They facilitate categorization of system classes into vertical hierarchies (Maciaszek, 2004). The qualitative research revealed that a layered structure is important for the portal to be able to provide adequate availability, accessibility, connection speed, update and content. "The quality of the organization's website regarding the availability, accessibility, content, e-services, update, and connection speed is very good so that led to the provision of good quality of e-services." (Interviewees \# 6 and 7). Also, the interviews reiterated the need for adequate layered structure of the portal to offer e-Government services (Interviewees \# 2, 8, 9, 10, 11, 12, 13, 14 and 15).

Interviewees confirmed the findings in the literature that Services Oriented Architecture (SOA) is important to OEGR. SOA is a solution which diminishes the dependency on back-end applications and reduces the requirement to write code every time there is a change in policy because it can deal with different platforms, and establishes new software that advances the direct collaboration of e-Government users irrespective of the delivery model (Behara et al., 2009; Oracle, 2010). "Yesser already applied IBM SOA suite in order to integrate different IT platforms (application and database) with the portal" (Interviewee \# 15). Interviewee \# 12 confirmed the need for implementing SOA as "the organization has many different platforms; we implemented the SOA tool to ease the integration for applications, databases and portal."

\subsection{Processes}

One of the important tools utilized to accomplish business process innovation is Business Process Reengineering (BPR) (Lee, 2010). Interviewees addressed the need for business processes tools to facilitate business work flow. "The organization has been aware of the advantages of BPR lately and has developed a plan for re-engineering the business processes" (Interviewees \# 1 and 14).

All officials interviewed also confirmed the importance of processes automations in OEGR by applying ICT application systems that manage and integrate the data objects to support the business functions in the Business Architecture (Ebrahim \& Irani, 2005b, Azab et al., 2009; Lee, 2010a) for example: (Interviewee \# 12) confirmed the importance of implementing multiple ICT applications: "The main ICT applications projects implemented at the organization were core business: civil affairs systems ("MGEEM", "SHOMOS", "TAM", Appointment system), passports, traffic, training system, Visa system, and ERP. Interviewees also discussed strategies for reassessing shared application systems and interconnecting them to ensure complete e-Government."

Data Warehousing is a collection of data from multiple sources, integrated into a data store (Bazerman, 2010). All Interviewees felt that data warehousing was necessity for data and information flow and some alluded to the lack of internal capacity for effective information management activities including producing, gathering, digitizing, processing, analyzing, distributing, accessing and archive information.

\subsection{ICT Infrastructure}

All interviewees confirmed the findings in the literature that ICT infrastructure is critical to support information systems and applications that are essential for OEGR (IBM, 2001; World Bank, 2006).

All interviewees also confirmed that e-Government ICT infrastructure possibly will include some technologies with a network infrastructure at its backbone; containing hardware and operating systems software (Alghamdi et al., 2011; IBM, 2011; Ebrahim \& Irani, 2005).

This qualitative research also confirmed the importance of connectivity which offers necessary technologies, such as Local Area Network (LAN), Wide Area Network (WAN), and high speed lines (Alghamdi et al., 2011; IBM, 2011; Ebrahim \& Irani, 2005). "The new ICT infrastructure projects include the organization's LAN and WAN (530 offices), renewed servers, a new Backup system and e-mail to ensure our organization e-Readiness" 
(Interviewee \# 8). Interviewee \# 1 stressed the importance of hardware, software and connectivity: "Although the organization's hardware, software and connectivity are highly developed, there is a problem in connecting to some specific small towns and villages through Internet Service Providers (ISPs) which has affects the organization's e-Readiness."

This qualitative finding revealed that ICT security is one of the most important factors and that organizations should emphasise solid security tools and policies to protect their information assets (Conklin et al., 2004; Pfleeger \& Pfleeger, 2003). "ICT Security is very vital for e-Government organizational readiness and should be viewed as a main priority... Any security breach in such systems would not only damage the organization's systems, but its image and credibility." (Interviewee \# 1). Interviewee \# 9 and12 confirmed the need of ICT security policies "The organization has advanced ICT security solutions and policies which are certified by ISO."

The in-depth interviews confirmed the importance and need for operations and maintenance processes to assist in monitoring and maintaining continuous ICT infrastructure and operating systems (Patrizio et al., 2004; Gil-Garcia \& Pardo, 2005). Interviewee \# 12 confirmed the importance of having Backup and Disaster Recovery (DR) "The Backup and DR systems are upgraded and updated regularly due to their importance". Also, Interviewee \# 15 stressed how everyday maintenance is fundamental for e-Readiness "Day-to-day operation and maintenance are essential for any IT department to resolve daily issues". Interviewee \# 4 and 9 confirmed the significance of implementing a help desk to handle the technical issues "Technical help desk is vital to fix technical issues such as PCs, printers, networks and applications" (Interviewee \# 6).

Also, this qualitative research revealed that some government organizations are more ready than others in ICT infrastructure in Saudi Arabia. The fifteen organizations' ICT readiness was under the average of internal capacity to pursue the following: Quality of software applications, quality of connectivity (WAN \& LAN), quality of ICT security, quality of hardware, and quality of technical support.

\subsection{Human Resources}

Human resources are one of the main factors in e-Government organizational readiness (APEC, 2008; Azab et al., 2009). Interviewees felt that having qualified people is critical for public organizations e-Government readiness (Interviewees \# 4, 11, 14 and 15):

"Lack of qualified ICT staff causes a delay in e-Government readiness" (Interviewees \# 4).

The qualitative findings reiterated findings in the literature that more in-depth ICT awareness is needed among policy makers, and employees at senior, middle management, and non-management positions (Azab et al., 2009; Bakry, 2004). "The policy makers have high level of awareness of the benefits of e-Government. However the department and sections managers have less awareness. Also, the awareness of users is low and should be considered to avoid delay in transforming to e-Government." (Interviewee \# 1). Interviewee \# 14 stressed the need of legislation to build awareness "We need to set legislations to increase ICT awareness in the organization for long term benefits."

Interviewees gave support to the importance of ICT management that specifies the managerial authority and accountability to encourage desirable behaviours in the use of IT to ensure e-Government readiness (Al-Omari \& Al-Omari, 2006). "Some government organizations are more ready than others in the adoption and diffusion of e-Government in Saudi Arabia due to lack of top management support" (Interviewees \# 3 and 6). Interviewee \# 11 confirmed the importance of delegating more authority to top managers "Top managers do not have authority to adopt e-Government. That caused another challenge in e-Readiness."

All Interviewees also stressed that when dealing with e-Government, a major challenge for organization e-Readiness is the lack of ICT training and skills in the public sector (Azab et al., 2009; Zaied et al., 2007; Yesser, 2013) for example:

"In this regard Yesser has been coordinated with the Ministry of Civil Service to provide six months IT certified training courses, the target is ninety thousand (90.000) employees in different government organizations." (Interviewee \# 15)

"The organization offers training courses, and license certificates for all employees to improve their ICT skills." (Interviewee \# 1, 4, 7 and 10).

Interviewees confirmed that ICT assistance through technical support can play a significant role for supporting important issues in the IT community to achieve e-Government readiness (Patrizio et al., 2004). Interviewees \# 1 and 10 confirmed the importance of continuous availability of help desk services: "An e-services help desk is 
available via the call centre $24 / 7$ and offers a dedicated assistant call number" (Interviewee \# 1).

\section{Conclusion}

This study extends the information systems e-Readiness and e-Government literatures by contributing a model to assess organizational e-Government readiness. Unlike existing e-Readiness studies, this study moves beyond the private sector organizations to examine applicability in the public sector context of e-Government. Furthermore, it extends e-Government models by more comprehensively incorporating a broader range of pertinent factors. Based on qualitative research with key government officials, the study uncovered vital factors of OEGR including strategy, user access, integration with national e-Government programs, portal, process, technology and people.

As the study includes perspectives of different e-Government specialists, guidelines relate to a range of actors from the public organizations in assisting them with evaluating their organization's e-Government readiness. These include CIOs, Project Managers, e-Government consultants, IT managers, E-Service Managers and Business Development Managers. Table 1 presents managerial implications arising from this study.

Table 2. Managerial implications

\begin{tabular}{|c|c|}
\hline Key Factor & Managerial Implications \\
\hline Strategy & $\begin{array}{l}\text { Leaders should create awareness of the strategy in each government organization. Steps should be taken to } \\
\text { ensure that the strategy has clear action plans and future plans. }\end{array}$ \\
\hline User access & $\begin{array}{l}\text { Mechanisms are needed to implement different delivery channels to allow multiple stakeholder including } \\
\text { citizens, other government departments, private firms and employees to access e-services. }\end{array}$ \\
\hline Yesser & $\begin{array}{l}\text { Coordination is essential with government organizations to ensure compatibility in connecting to GSN and } \\
\text { GSB. Respective government organizations should be involved in early phases of government sector strategy } \\
\text { plans. }\end{array}$ \\
\hline Portal & $\begin{array}{l}\text { Integrating website portal activities with internal processes should be among the top priorities in any } \\
\text { e-government strategy. The portal should be service oriented with available and well-structured services to } \\
\text { ensure effective access to stakeholders. }\end{array}$ \\
\hline Processes & $\begin{array}{l}\text { Emphasis should be placed digitizing information in improve data management. Business processes should } \\
\text { also be reengineered to automate work processes. }\end{array}$ \\
\hline ICT infrastructure & $\begin{array}{l}\text { Policy makers should aware that despite the many plans to enhance the country's ICT infrastructure, this } \\
\text { study revealed that it is still deficient in rural areas. Also integration between organizations and branches is } \\
\text { not satisfactory which has affected OEGR. Therefore, a focus on connectivity is essential. }\end{array}$ \\
\hline Human resources & $\begin{array}{l}\text { Involving employees throughout the different stages consultation should be encouraged to leverage on their } \\
\text { experience and foster commitment to the initiative and less resistance to change. More technical help and } \\
\text { training should be provided to employees to increase OEGR. }\end{array}$ \\
\hline
\end{tabular}

Despite its valuable managerial implications, further work is necessary. First, the study can be replicated in other countries to facilitate cross-country comparisons and benchmarking of OEGR particularly in the Arab and Muslim world, to observe if a comparable finding can be accomplished. Second, a longitudinal study analysing both the views of employees and management may contribute to pertinent strategies to improve capability and progress towards e-Government and public sector transformation over time in public sector organizations. Third, a quantitative study will also be useful in testing this OEGR assessment model. This can be achieved by carrying out the same study in other developed and developing countries. The study was limited only to organisational and technological issues at the organizational level in Saudi Arabia. However, since the country's legal system is derived from Islamic law, additional research can investigate the effect of the country's laws and its corresponding culture and leadership style on OEGR. Nevertheless, this study represents important issues towards developing a comprehensive OEGR model.

\section{References}

Al-Omari, A., \& Al-Omari, H. (2006). E-Government Readiness Assessment Model. Journal of Computer Science, 2(11), 841-845. http://dx.doi.org/10.3844/jcssp.2006.841.845

Al-Osaimi, K. (2007). Mathematical Models for E-Readiness Assessment of Organizations with Intranets.

Al-Solbi, A. N. H. (2008). An exploratory study of factors determining e-government success in Saudi Arabia. The International Business Information Management Association (IBIMA). 
Alghamdi, I., Goodwin, R., \& Rampersad, G. (2011). E-Government Readiness Assessment for Government Organizations in Developing Countries. Computer and Information Science, 4(3), 3-17. $\mathrm{http}: / / \mathrm{dx}$. doi.org/10.5539/cis.v4n3p3

Alshehri, M., \& Drew, S. (2010). Challenges of e-Government Services Adoption in Saudi Arabia from an e-Ready Citizen Perspective. World Academy of Science, Engineering and Technology, 42, 1039-1045.

Alsobhi, F. M., \& Weerakkody, V. (2009). Current State of E-services in Saudi Arabia: The Case of Intermediaries in Facilitiing Government Services in Madinah City. European and Mediterranean Conference on Information Systems. Crown Plaza Hotel, Izmir.

Andersen, K. V. (2010). E-government and Public Sector Process Rebuilding: Dilettantes, Wheel Barrows, and Diamonds Springer (1st ed.).

APEC. (2008). E-Commerce Readiness Assessment Initiative. APEC.

Azab, N. A., Kamel, S., \& Dafoulas, G. (2009). A Suggested Framework for Assessing Electronic Government Readiness in Egypt. Electronic Journal of E-Government, 7(1), 11-28.

Bakry, S. H. (2004). Development of e-Government: A STOPE view. International Journal of Network Management, 14(4), 339-350. http://dx.doi.org/10.1002/nem.529

Bazerman, M. (2010). Announcing IACM 2010 23rd Annual Conference Abstracting. E-Journal Social Science Electronic Publishing, Inc.

Behara, V. V. (2009). Service Oriented Architecture for E-Governance. BP Trends.

Blaxter, L., Hughes, C., \& Tight, M. (Eds.). (2001). How to Research, Buckingham and Philadelphia. Open University Press.

Bridges. (2005). E-readiness assessment: Who is Doing What and Where? Retrieved from http://www.cspp.org

Carson, D., Gilmore, A., Gronhaug, K., \& Perry, C. (Eds.). (2001). Qualitative Research in Marketing. London: Sage.

Chappell, D. A. (2004). Enterprise Service Bus. USA: O’Reilly Media, Inc.

Chen, H. (2002). Issue Digital Government: technologies and practices. Decision Support Systems, 34, $223-227$. http://dx.doi.org/10.1016/S0167-9236(02)00118-5

Conklin, A., Williams, D., White, G., \& Davis, R. (2004). Principles of Computer Security Corel VENTURA. Illinois, USA: Corel VENTURA.

Ebrahim, Z., \& Irani, Z. (2005b). E-government adoption: Architecture and Barriers. Business Process Management Journal, 11(5), 589-611. http://dx.doi.org/10.1108/14637150510619902

Gil-Garcia, J. R., \& Pardo, T. A. (2005). E-government success factors: Mapping practical tools to theoretical foundations. Government Information Quarterly. http://dx.doi.org/10.1016/j.giq.2005.02.001

Gonzalez, R., Gasco, J., \& Llopis, J. (2007). E-government success: some principles from a Spanish case study. Industrial Management \& Data Systems, 107(6), 845-861. http://dx.doi.org/10.1108/02635570710758752

Haug, A. S. (2011). IT readiness in small and medium-sized enterprises.

Heeks, R. (2005a). E-Government as a Carrier of Context. Journal of Public Policy, 25(1), 51-74. http://dx.doi.org/10.1017/S0143814X05000206

Heeks, R. (2005b). Implementing and Managing E-Government: An International Text. Sage Publishers.

IBM. (2011). ICT Infrastructure. Retrieved from http://www.ibm.com

ICEGD. (2002). The International Conference on E-Government for Development.

Koh, C. E., Nam, K. T., \& Prybutok, V. R. (2007). A value chain perspective of internet practices, e-readiness and organizational performance: A comparison of US and South Korean firms. Industrial Management \& Data Systems, 107(4), 519-536. http://dx.doi.org/10.1108/02635570710740670

Kumar, R. (1996). Research Methodology: A Step-By-Step Guide for Beginners. Longman: South Melbourne.

Kuo, Y. L. (2013). Technology readiness as moderator for construction company performance. Industrial Management \& Data Systems, 113(4), 558-572. http://dx.doi.org/10.1108/02635571311322793

Layne, K., \& Lee, J. (2001). Developing fully functional E-government: A four stage model. Government Information Quarterly, 18(2), 122-136. http://dx.doi.org/10.1016/S0740-624X(01)00066-1 
Lee, Y. N. (2010). E-Government Application. UN-APCICT. Retrieved from http://www.unapcict.org/academy

Maciaszek, L. A. (2004). International Conference on Enterprise Information Systems.

Maheshwari, B., Vinod Kumar, U. K., \& Sharan, V. (2009). E-Government Portal Effectiveness: Managerial Considerations for Design and Development.

Miles, M. B., \& Huberman, A. M. (Eds.) (1994). An Expanded Sourcebook: Qualitative Data Analysis. Thousands Oaks: Sage.

Millard, J. (2007). European e-Government 2005-2007. Retrieved from http://www.epractice.eu/files/download/awards/ResearchReport2007.pdf

Moon, M. J. (2002). The evolution of e-government among municipalities: rhetoric or reality? Public Administration Review, 26(4), 424-434. http://dx.doi.org/10.1111/0033-3352.00196

Nfuka, E. N., \& Rusu, L. (2007). The effect of critical success factors on IT governance performance. Industrial Management \& Data Systems, 111(9), 1418-1448. http://dx.doi.org/10.1108/02635571111182773

Niosi, J. (2006). Introduction to the symposium: universities as a source of commercial technology. Journal of Technology Transfer, 31(4), 399-402. http://dx.doi.org/10.1007/s10961-006-0001-0

Norris, D. F., \& Lloyd, B. A. (2006). The Scholarly Literature on E-Government: Characterising a Nascent Field. International Journal of Electronic Government Research, 2(4), 40-56. http://dx.doi.org/10.4018/jegr.2006100103

OECD. (2003). E-Government Studies: The E-Government Imperative. OECD Publishing.

Ojiako, U. (2012). Using IS/IT to enhance service delivery. Industrial Management \& Data Systems, 112(4), 584-599. http://dx.doi.org/10.1108/02635571211225495

Oracle. (2010). Oracle portal $\quad$ Oracle. $\quad$ Retrieved from http://education.oracle.com/pls/web_prod-plq-dad/db_pages.getCourseDesc?dc=D68842GC20

Parasuraman, A. (2000). Technology readiness index (TRI): a multiple-item scale to measure readiness to embrace new technologies. Journal of Service Research, 2(4), 307-320. http://dx.doi.org/10.1177/109467050024001

Patrizio, D. N., Isabella, M., Rocca, G. L., \& Valentina, T. (2004). ICT Infrastructure-The Regional Dimension. Benchmarking the Information Society: e-Europe Indicators for European Regions. BISER.

Pfleeger, C. P., \& Pfleeger, S. L. (2003). Security in Computing. USA, NJ: Prentice Hall.

Rojko, K., Lesjak, D., \& Vehovar, V. (2011). Economic crisis Information communication technology spending in. Industrial Management \& Data Systems, 111(3), 391-409. http://dx.doi.org/10.1108/02635571111118279

Safai-Amin, M. (2002). Information technologies: challenges and opportunities for local governments. Journal of Government Information, 27, 471-479. http://dx.doi.org/10.1016/S1352-0237(00)00180-5

Stauffacher, G. (2002). E-Government as and Instrument of Public Management Reform (2nd ed.). E-Government Conference.

Ticehurst, C. G., \& Veal, T. R. (Eds.) (2000). Business Research Methods: A Managerial Approach. Australia: Pearson Education Pty Limited.

UNDPEPA/ASPA. (2002). Benchmarking e-government: A global perspective. Retrieved from http://www.itpolicy.gov.il/topics_egov/docs/benchmarking.pdf

United Nations. (2008, 2010, 2012). UN E-Government Survey from E-Government to Connected Governance, Department of Economic and Social Affairs. Administration and Development Management, United Nations Online Network in Public Administration and Finance (UNPAN). USA: Division for Public, United Nations Publications.

WEF. (2011). World Economic Forum Global Information Technology Report 2010-2011: Transformations 2.0.

World Bank (2005). E-Ready for What? E-Readiness in Developing Countries: Current Status and Prospects toward the Millennium Development Goals.

World Bank. (2006). Information and Communications for Development 2006: Global Trends and Policies. World Bank Publications. 
Yesser. (2005). Supporting plans and methodologies: (a) E-Readiness assessment methodology for government organizations. Retrieved from http://www.yesser.gov.sa/en/Pages/default.aspx

Yesser. (2013). E-government Transactions' Methodologies \& Handbooks. Retrieved from http://www.yesser.gov.sa/en/Methodologies/mechanisms/Pages/e_government_transactions.aspx

Yin, R. K. (Ed.) (2009). Case Study Research: Design and Methods (Applied Social Research Methods). US: Sage Publications Inc.

Zaied, A. N. H., Khairalla, F. A., \& Al-Rashid, W. (2007). Assessing e-Readiness in the Arab Countries: Perceptions Towards ICT Environment in Public Organisations in the State of Kuwait. The Electronic Journal of E-Government, 5(1), 77-86.

\section{Copyrights}

Copyright for this article is retained by the author(s), with first publication rights granted to the journal.

This is an open-access article distributed under the terms and conditions of the Creative Commons Attribution license (http://creativecommons.org/licenses/by/3.0/). 